\title{
Myiasis Complicating Basal Cell Carcinoma in a 72 Year Old Male
}

\author{
Authors \\ Dr Ritu Rani ${ }^{1}$, Dr Manvi Katoch ${ }^{2}$, Dr Reena K Sharma ${ }^{3}$, Dr Mudita Gupta ${ }^{4}$ \\ ${ }^{1}$ Dermatologist, Civil Hospital Kangra,H.P. \\ ${ }^{2}$ Anaesthesiologist, Zonal Hospital Dharamshala \\ ${ }^{3}$ Dermatologist, Civil Hospital Kangra \\ ${ }^{4}$ Assistant Professor, Department of Dermatology, IGMC, Shimla \\ *Corresponding author \\ Dr Manvi Katoch \\ Anaesthesiologist, Zonal Hospital Dharamshala, India
}

\begin{abstract}
Myiasis is often seen associated with malignant conditions like basal cell carcinoma (BCC) or squamous cell carcinoma (SCC). The neglected nature and poor socioeconomic status of the patients play a contributory role in maggot infestation in these malignancies. Physical removal of the larvae is the mainstay of treatment. We described a neglected ulcerated BCC with maggot infestation in a 72 year old male.
\end{abstract}

Keywords: myiasis; poor hygiene; socioeconomic; turpentine oil.

\section{Introduction}

Myiasis is defined as infestation of body tissues by dipterous larvae. It is often seen with malignant conditions such as basal cell or squamous cell carcinoma. ${ }^{[1]}$ Giant skin cancers with size more than $5 \mathrm{~cm}$ are associated with a significantly increased risk of complications and mortality. Poor hygiene and low socioeconomic status lead to maggot infestation in wounds. We present a rare case of cutaneous myiasis located on a giant basal cell carcinoma of the face in an elderly male.

\section{Case Report}

A 72 year old male presented to us with a giant foul smelling painful ulcerative lesion on the left side of face from last 6 months. The lesion has been progressing in size since the onset. He recently noticed presence of some live worm-like organisms on the surface of the lesion. On examination there was a single ulcerated plaque of size $10 \times 7 \mathrm{~cm}$ approximately with rolled margins involving the left side of face extending from infraorbital area to the retroauricular region (Figure 1). Live fly larvae were seen crawling onto the walls of the ulcerated plaque (Figure 2). The lesion was flooded with turpentine oil following which they were manually removed with the help of forceps. The routine investigations were within normal limits. Biopsy from the edge of the lesion was taken and sent for histopathological examination. The biopsy revealed an epithelial neoplasm made up of tumor islands that vary greatly in size and shape. The tumor islands were made up of small round cells that show peripheral palisading. The nuclei were 
uniformly stained and occasional pyknotic cells were scattered between these cells. The surrounding stroma showed mucin and a moderately dense perivascular lymphoplasmocytic infiltrate. The tumor islands were separated from this stroma by a cleft at few places. The findings were consistent with basal cell carcinoma. The patient was started on oral antibiotics and analgesics and called for follow up at 2 weeks for further management.

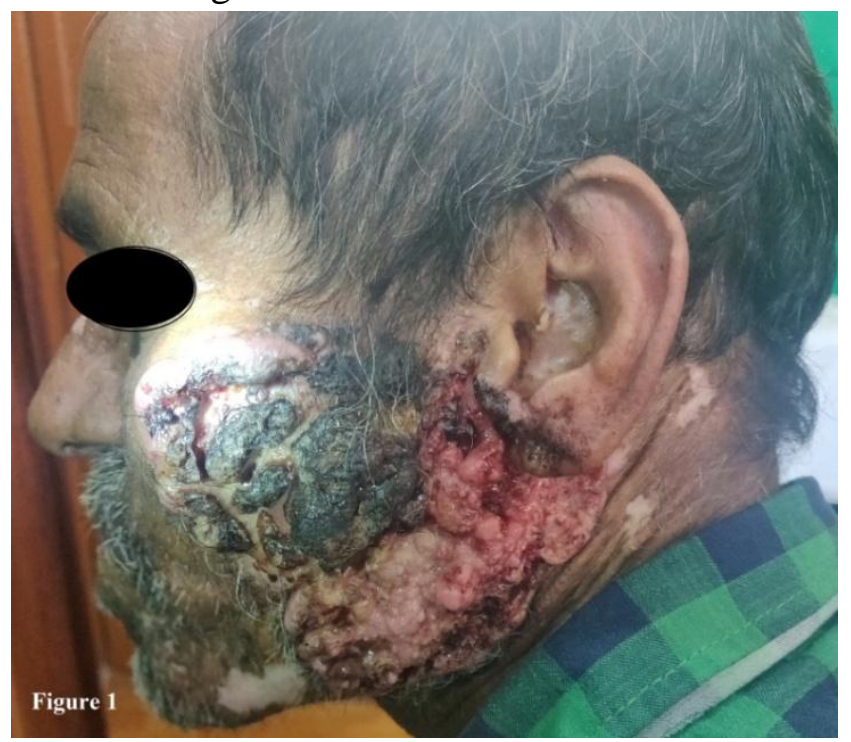

Figure 1. A single, ulcerated plaque on the left side of face with areas of necrosis and rolled up edges.

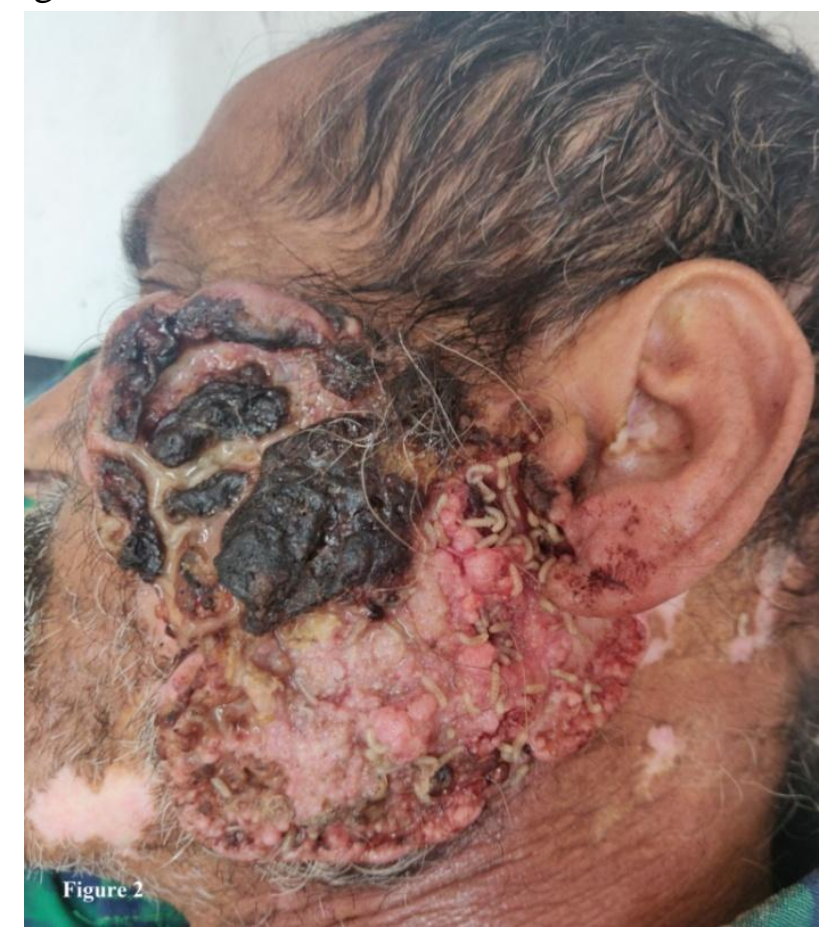

Figure 2. Multiple, live cream colored larvae seen after flooding the lesion with turpentine oil.

\section{Discussion}

Myiasis is defined as the infestation of live vertebrate animals with dipterous larvae which feed on the host tissue. ${ }^{[2]}$ It is more frequently seen in elderly people who cannot maintain self- hygiene or suffering from mental disorders, or immunodeficiencies. ${ }^{[3,4]}$

Francesconi et al classified myiasis on the basis of based on entomological and anatomical point

of view. Entomologically the three myiasis producing groups identified were obligatory, facultative, and accidental. Based on their anatomical location they were divided into sanguinivorous, cutaneous myiasis, wound myiasis and cavitary myiasis. The cutaneous myiasis as the name suggests is confined to the skin and is more common than the other forms. ${ }^{[2]}$

The entomological assessment identifies the larvae as C. bezziana, also known as old world screwworm, belonging to the fly family Calliphoridae. ${ }^{[2]}$

The risk factors which play an important role in the infestation of the tissue by maggots are poor hygiene, low socioeconomic status, advanced age, chronic alcoholics or diseases like diabetes mellitus and peripheral vascular diseases, and mental disorders. ${ }^{[5,6]}$ The malignant conditions which have been associated with myiasis include angiosarcoma, laryngeal carcinoma, breast carcinomna, Kaposi's sarcoma, non-Hodgkin's lymphoma, cervical cancer or skin tumours. ${ }^{[7,8]}$

Malignant conditions like BCC and SCC have been found to be associated with myiasis frequently but underreported. The study done by Rubio et al, reported three cancer-associated myiasis, one laryngeal carcinoma infested by Chrysomya, two cutaneous BCC infested by Sarchophaga. ${ }^{[9]}$

The mainstay of treatment is removal of larvae and the subsequent treatment of secondary infections. The removal of the larvae with the help of forceps provide the symptomatic relief immediately. ${ }^{[10]}$ There are various methods of wound ooclusion that can be used to force the larvae to come out of the tissue so that they can be 
easily removed. Turpentine oil, as used in our case, results in local asphyxia and the death of maggots. The other options which can be used to create occlusion are petroleum, animal fat, beeswax, butter, liquid paraffin, hair gel, nail polish, mineral oil and polymyxin $B .{ }^{[1]}$ The surgical debridement of the necrotic tissue followed by pressure irrigation may also be required. In our case report we have described wound myiasis as a complication of neglected ulcerated basal cell carcinoma of the face.

\section{Conclusion}

Myiasis complicating malignant tumours like BCC has been underreported till date. We hereby described an uncommon case of myaisis as a complication of neglected ulcerated BCC.

\section{References}

1. Francesconi F, Lupi O. Myiasis. Clin Microbiol Rev. 2012;25(1):79-105.

2. Kwong A, Yiu WK, Chow LW, Wong S. Chrysoma bezziana: A rare infestation of the breast. Breast J 2007;13:297-301.

3. Bayindir T, Cicek MT, Atambay M, Kizilay A. Cutaneous myiasis in a malignant wound of the head and neck region. J Craniofac Surg 2012;23:e19- 20.

4. Kamal S, Bodh SA, Kumar S, Goel R. Orbital myiasis complicating squamous cell carcinoma in xeroderma pigmentosum. Orbit 2012;31:137- 9.

5. Villwock JA, Harris TM. Head and neck myiasis, cutaneous malignancy, and infection: a case series and review of the literature. J Emerg Med. 2014;47(2):e3741.

6. Raposo AA, Schettini AP, Massone C. Concurrent primary and secondary myiasis on basal cell carcinoma. An Bras Dermatol. 2012;87(2):292-295.
7. Gopalakrishnan S, Srinivasan R, Saxena SK, Shanmugapriya J. Myiasis in different types of carcinoma cases in southern India. Indian J Med Microbiol. 2008;26(2):189192.

8. Nawin Kumar, Rajesh Parameshwaran Nair,Anuja Sinha, Amit Kumar. Myiasis in a case of invasive ductal carcinoma breast - A rare presentation. Med Res Chron. 2014;1(2) 208-2012.

9. Robio C, Ladro.n de Guevara C, Martin MA, Campos L,uesada A, Casado M. Cutaneous myiasis over tumor-lesions: Presentation of three cases. Actas Dermosifiliorg 2006;97:39-42.

10. Arbit E, Varon RE, Brem SS. Myiatic scalp and skull infection with diptera Sarcophaga: case report. Neurosurgery. 1986;18(3):361-362. 